\title{
Erratum to: Science, Museums and Collecting the Indigenous Dead in Colonial Australia
}

\section{Erratum to:}

P. Turnbull, Science, Museums and Collecting the Indigenous Dead in Colonial Australia, Palgrave Studies in Pacific History, https://doi.org/10.1007/978-3-319-51874-9

The original version of this book was revised. The author's affiliation was updated to "University of Tasmania, Launceston, TAS, Australia" and "University of Queensland, Brisbane, QLD, Australia". 